\title{
KEDUDUKAN HARTA DAN IMPLIKASINYA DALAM PERSPEKTIF AL-QUR'AN DAN HADIS
}

\author{
Asnaini, Riki Aprianto \\ IAIN Bengkulu \\ Email: asnaini@iainbengkulu.ac.id,rikiapriantosl@gmail.com
}

\begin{abstract}
The problem about position of assets really to be studied at this time, considering the increasing number of people who abuse assets. In the perspective of Qor'an and Hadist, property is absolutely God's. Treasure as jewelry that adds happiness in life, as a test of faith, and as a provision for worship. The implication of the status of this property is the accuracy of its utilization. The use of assets must always be in the frame of devotion to Allah or as much as possible to taqarrub the illusion of Allah (draw closer to Allah).

Keywords: Asset, Utilization, Qur'an, Hadith
\end{abstract}

Abstrak: Permasalahan tentang kedudukan harta sangat perlu dikaji saat ini, mengingat semakin banyaknya manusia yang menyalahgunakan harta. Dalam perspektif Alquran dan Hadis, harta secara mutlak adalah milik Allah. Harta sebagai perhiasan yang menambah kebahagiaan dalam hidup, sebagai ujian keimanan, dan sebagai bekal ibadah. Implikasi kedudukan harta ini adalah pada ketepatan pemanfaatannya. Pemanfaatan harta harus senantiasa dalam bingkai pengabdian kepada Allah atau sebesar-besarnya untuk taqarrub ilalAllah (mendekatkan diri kepada Allah).

Kata Kunci: Kedudukan Harta, Pemanfaatan, Alquran, Hadis

\section{A. Pendahuluan}

Harta merupakan karunia Allah SWT untuk umat manusia, ia bagaikan perhiasan yang bisa menambah indahnya kehidupan di dunia, ia merupkan suatu hal yang selalu dipikirkan oleh manusia, bahkan banyak orang yang mengorbankan tenaga dan fikirannya untuk memperoleh harta sebanyakbanyaknya. Banyak manusia beranggapan bahwa orang sukses adalah orang yang mampu mengumpulkan pundi-pundi harta sebanyak-banyaknya, orang belum disebut sukses jika belum mempunyai banyak harta. ${ }^{1}$ Agaknya penyakit materialis inilah yang terjadi pada zaman sekarang, manusia

${ }^{1}$ Hendi Suhendi, Fiqh Muamalah (Jakarta: Rajawali Press, 2005), hlm. 9 mempunyai standar kesuksesan diukur dari banyaknya harta yang dimiliki.

Islam mengakui bahwa eksistensi harta sangat penting untuk mendukung penyempurnaan hidup manusia, mempermudah pemenuhan kebutuhan di dunia dan pelaksanaan ibadah baik yang ritual ataupun sosial, bahkan jihad salah satunya harus dengan harta. Oleh sebab itu, Islam melalui Alquran dan hadis memberikan tuntunan mengenai harta, agar manusia bisa memposisikan harta dengan benar untuk meraih keselamatan dan kebahagiaan di dunia dan akhirat sebagaimana tujuan aktifitas ekonomi Islam.

\section{B. METODE PENELITIAN}

Penelitan ini menggunakan penelitian kualitatif dengan pendekatan literatur review. Tujuan literatur review 
adalah untuk mendapatkan landasan teori yang bisa mendukung pemecahan masalah yang sedang diteliti. Data diperoleh dengan menggunakan dokumentasi yang merupakan data sekunder yang diambil dari buku-buku. Teknik analisis data dengan menggunakan analisis isi (content analysis).

\section{PEMBAHASAN}

\section{Pengertian Harta}

Harta dalam bahasa Arab disebut al-mal yang berasal dari kata maalayamiilu-mailan, yang berarti condong, cenderung dan miring. ${ }^{2}$ Secara etimologi harta adalah segala sesuatu yang menyenangkan manusia dan mereka pelihara, baik dalam bentuk materi maupun dalam manfaat. $^{3}$ Sedangkan arti harta secara terminologi adalah: "sesuatu yang digandrungi tabiat manusia dan memungkinkan untuk disimpan hingga dibutuhkan." (Ibnu Abidin dari golongan Hanafi). ${ }^{4}$ Sedangkan oleh ulama Hanafi yang lain disebutkan "Harta adalah segala sesuatu yang dapat dihimpun, disimpan (dipelihara) dan dapat dimanfaatkan menurut adat (kebiasaan)". Definisi lain

${ }^{2}$ H. Hendi Suhendi, Figh Muamalah, (Jakarta: PT Raja Grafindo Persada, 2002), hlm. 9

${ }^{3}$ M. Ali Hasan, Berbagai Macam Transaksi dalam Islam, (Jakarta: PT Raja Grafindo Persada, 2003), hlm. 55

${ }^{4}$ M. Ali Hasan, Berbagai Macam..., hlm.55 menyebutkan bahwa Harta adalah "segala sesuatu yang mempunyai nilai, dan diwajibkan ganti rugi atas orang yang merusak atau melenyapkannya." (Jumhur ulama selain Hanafiyah). ${ }^{5}$

Menurut Jumhur Ulama antara harta dan hak milik adalah sama, sementara menurut ulama Hanafiyah membedakan antara hak milik dengan harta: ${ }^{6}$ Hak milik adalah "sesuatu yang dapat digunakan secara khusus dan tidak dicampuri penggunaannya oleh orang lain". Sedangkan harta adalah "segala sesuatu yang dapat disimpan untuk digunakan ketika dibutuhkan, dalam penggunaannya bisa dicampuri orang lain. Harta merupakan sesuatu yang digandrungi tabiat manusia dan memungkinkan untuk disimpan hingga dibutuhkan. Harta adalah segala sesuatu yang dapat disimpan untuk digunakan ketika dibutuhkan, dalam penggunaannya bisa dicampuri oleh orang lain, maka menurut Hanāfiah yang dimaksud harta hanyalah sesuatu yang berwujud ( $a$ 'yān)." Tiga mazhab lainnya mendefinisikan sebagai berikut:

a. Ma hab Mālikī mendefinisikan hak milik menjadi dua macam. Pertama, adalah hak yang melekat pada

\footnotetext{
${ }^{5}$ M. Ali Hasan, Berbagai Macam..., hlm.56

${ }^{6}$ Lukman Hakim, Prinsip-prinsip Ekonomi Islam,(Jakarta: Erlangga, 2012), hlm. 14
} 
seseorang yang menghalangi orang lain untuk menguasainya. Kedua, sesuatu yang diakui sebagai hak milik secara 'urf (adat).

b. Ma hab Syafi'i mendefinisikan hak milik juga menjadi dua macam. Pertama, adalah sesuatu yang bermanfaat bagi pemiliknya; kedua, bernilai harta.

c. Mazhab Hambali juga mendefinisikan hak milik menjadi dua macam. Pertama, sesuatu yang mempunyai nilai ekonomi; kedua, dilindungi undang-undang.

Dalam Kompilasi Hukum Syariah, pasal 1 ayat 6 amwāl (harta) adalah benda yang dapat dimiliki, dikuasai, diusahakan, dan dialihkan, baik benda berwujud maupun tidak berwujud, baik yang terdaftar maupun yang tidak terdaftar, baik benda bergerak maupun benda yang tidak bergerak dan hak yang memiliki nilai ekonomis. Definisi harta dalam Kompilasi Hukum Ekonomi Syariah sepertinya adalah mengambil intisari dan mencoba merangkum defenisidefenisi yang dikemukakan oleh para fuqaha'.

Dari pendapat di atas, setidaknya ada empat hal yang ada dalam harta/hak milik: 1) Sesuatu yang dapat diambil manfaat; 2) Sesuatu yang mempunyai nilai ekonomi; 3)Sesuatu yang secara 'urf (adat yang benar) diakui sebagai hak milik; 4) Adanya perlindungan undang-undang yang mengaturnya.

Pendapat di atas, juga menjelaskan bahwa terdapat perbedaan mengenai esensi harta. Oleh jumhur ulama dikatakan, bahwa harta tidak saja bersifat materi, tetapi juga termasuk manfaat dari suatu benda, karena yang dimaksud adalah manfaat, bukan zatnya (bendanya). Menurut Hanafiyah bahwa harta mesti dapat disimpan, maka sesuatu yang tidak dapat disimpan tidak dapat disebut harta, maka manfaat menurut Hanafiyah tidak termasuk harta, tetapi manfaat termasuk milik. Hanafiyah membedakan harta dengan milik, yaitu: "Milik adalah sesuatu yang dapat digunakan secara khusus dan tidak dicampuri penggunaannya oleh orang lain. Harta adalah segala sesuatu yang dapat disimpan untuk digunakan ketika dibutuhkan, dalam penggunaannya bisa dicampuri oleh orang lain. Jadi menurut Hanafiyah yang dimaksud harta hanyalah sesuatu yang berwujud.

Dari sekumpulan definisi yang telah dikemukakan oleh para fuqaha, 
Teungku menyimpulkan bahwa: $^{7}$

Harta (mal) adalah:

a. nama bagi yang selain manusia, yang ditetapkan untuk kemaslahatan manusia, dapat dipelihara pada suatu tempat, dapat dilakukan tasharruf dengan jalan ikhtiyar;

b. sesuatu yang dapat dimiliki oleh setiap manusia, baik oleh seluruh manusia maupun oleh sebagian manusia;

c. sesuatu yang sah untuk diperjualbelikan;

d. sesuatu yang dapat dimiliki dan mempunyai nilai;

e. sesuatu yang dapat disimpan dalam waktu yang lama atau sebentar dan dapat diambil manfaatnya ketika dibutuhkan. $^{8}$

Menurut para fuqaha bahwa harta bersendi pada dua unsur, unsur 'ainiyah dan unsur 'urf. Unsur 'ainiyah adalah "bahwa harta itu ada wujudnya dalam kenyataan (a'yan), maka manfaat seluruh rumah yang dipelihara manusia tidak disebut harta, tetapi masuk milik atau hak." ${ }^{9}$ Unsur 'urf adalah segala sesuatu yang

${ }^{7}$ Teungku Muhammad Hasbi Ash Shiddieqy, Pengantar Fiqh Muamalah, (Semarang: PT. Pustaka Rizki Putra, 2001), hlm. 154 hlm. 10

${ }^{8}$ H. Hendi Suhendi, Fiqh Muamalah...,

${ }^{9}$ Teungku Muhammad Hasbi Ash Shiddieqy, Pengantar Fiqh..., hlm. 154 dipandang harta oleh seluruh manusia atau sebagian manusia, dapat diberi atau tidak diberi. Maka sesuatu yang tidak berlaku demikian, tidak dipandang harta walaupun benda, seperti manusia yang merdeka, sepotong roti dan secupak tanah. Maka manusia itu walaupun merupakan suatu benda, suatu tubuh, namun tidak bisa dikatakan harta. ${ }^{10}$

\section{Kedudukan Harta}

Harta mempunyai kedudukan yang sangat penting dalam kehidupan manusia. Hartalah yang dapat menunjang segala kegiatan manusia, termasuk untuk memenuhi kebutuhan pokok manusia (sandang, papan dan pangan). Menjaga harta adalah termasuk lima urusan pokok manusia yang harus dijaga, yaitu memelihara agama, jiwa, akal, kehormatan (keturunan) dan harta. ${ }^{11}$ Kemudian seseorang yang diberi kesempatan oleh Allah memiliki harta, banyak atau sedikit, maka tidak boleh sewenangwenang dalam menggunakan (memfungsikan) hartanya. Kebebasan seseorang untuk memiliki dan memanfaatkan hartanya adalah sebatas yang dibenarkan oleh syara'.

\footnotetext{
${ }^{10}$ Teungku Muhammad Hasbi Ash Shiddieqy, Pengantar Fiqh..., hlm. 154

${ }^{11}$ Teungku Muhammad Hasbi Ash Shiddieqy, Pengantar Hukum Islam, (Semarang: PT Pustaka Rizki Putra, 2001), hlm. 345
} 
Harta adalah sebagai titipan, maka manusia tidak memiliki harta secara mutlak, karena itu menurut pandangan ekonomi Islam di dalam harta, terdapat hak-hak orang lain, seperti zakat, sedekah, dan infak. ${ }^{12}$ Dalam firman Allah surat AdzDzariyat ayat 19 disebutkan: "Dan pada harta-harta mereka, ada hak untuk orang miskin yang meminta dan orang miskin yang tidak mendapat bagian". ${ }^{13}$ Di dalam hadis Rasulullah saw bersabda: "Sesungguhnya pada setiap harta (seseorang), ada hak (orang lain) selain zakat" (H.R. Tirmidzi).

Intinya, bahwa kedudukan harta adalah sebagai amanah atau titipan Allah SWT kepada manusia. Dan karena itu adalah titipan, maka manusia berkewajiban untuk menggunakan harta tersebut sebesarbesarnya untuk mengabdi kepada Allah. Tidak diperbolehkan untuk maksiat, tidak boleh membelanjakannya secara berlebihan (boros, mubadzir) atau menelantarkannya sehingga tidak bermanfaat. Manusia harus memastikan agar hartanya itu digunakan untuk taqarrub ilalAllah

${ }^{12}$ H. Hendi Suhendi, Fiqh Muamalah..., hlm.

\footnotetext{
${ }^{13}$ Alquran dan Terjemahannya, hlm. 755
}

(mendekatkan diri kepada Allah) atau berfungsi untuk kemaslahatan dunia dan akhirat.

\section{Pembagian Harta dan Akibat Hukumnya}

Menurut para fuqaha harta dapat ditinjau dari beberapa segi. Harta terdiri dari beberapa bagian, dan masing-masing memiliki ciri khusus dan hukumnya tersendiri. Berikut adalah beberapa pembagian harta menurut golongan masing-masing dan menurut hukum masing-masing: ${ }^{14}$

Pertama, mal mutaqawwim dan ghair mutaqawwim. Mal mutaqawwim atau harta yang berharga ialah setiap harta yang disimpan oleh seseorang dan syara' mengharuskan penggunaannya dan cara yang digunakan untuk memperolehnya adalah dengan jalan yang baik yang dibenarkan oleh syara'. Contohnya: seperti daging kambing adalah halal dimakan, tetapi jika dalam penyembelihannya menggunakan cara yang tidak dibenarkan oleh syara', maka daging kambing itu menjadi batal menurut syara'. Jadi dalam kasus seperti ini ada hal yang tidak memperbolehkan untuk memanfaatkan harta itu (seperti kasus daging kambing ini). Sedangkan mal 
ghayr mutaqawwim atau harta yang tidak berharga ialah harta yang tidak di dalam simpanan atau dimiliki orang, atau harta yang tidak boleh diambil manfatnya baik itu jenis, cara memperolehnya maupun cara penggunaannya. Harta yang seperti ini adalah kebalikan dari harta yang berharga.

Kedua, mal mitsli dan mal qimi. Mal mistsli ialah harta yang ada sebanding atau serupa dengannya tanpa terdapat berlebih kurang dalam semua juzu`nya (fisik, bagianbagiannya) atau dengan kata lain harta yang jenisnya mudah diperoleh secara persis. Harta yang seperti ini adalah harta yang cara memperolehnya sangat mudah didapat dan banyak sekali persamaannya. Mal Qimi ialah harta yang tidak terdapat padanannya lagi di pasaran atau terdapat padananya, akan tetapi nilai tiap satuannya berbeda. Dalam perjalanannya, harta mistsli bisa berubah menjadi harta qimi atau sebaliknya, dengan ketentuan sebagai berikut:

a. Jika harta mitsli susah untuk didapatkan di pasaran (terjadi kelangkaan atau scarcity), maka secara otomatis berubah menjadi harta qimi;

b. Jika terjadi percampuran antara dua harta mitsli dari dua jenis yang berbeda, seperti modifikasi Toyota dan Honda, maka mobiltersebut menjadi harta qimi;

c. Jika harta qimi terdapat anyak padanannya di pasaran, maka secara otomatis menjadi harta mitsli.

Pembagian harta mitsli dan qimi memiliki implikasi hukum sebagai berikut:

a. Harta mitsli bisa

menjadi tsaman (harga) dalam jualbeli hanya dengan menyebutkan jenis dan sifatnya, sedangkan harta qimi tidak bisa menjadi tsman. Jika harta qimi dikaitkan dengan hakhak finansial, maka harus disebutkan secara detail, karena hal itu akan mempengaruhi nilai yang dicerminkannya, seperti domba Australia, tentunya akan berbeda nilainya dengan domba Indonesia, walaupun mungkin jenis dan sifatnya sama.

b. Jika harta mitsli dirusak oleh orang, maka wajib diganti dengan padanannya yang mendekati nilai ekonomisnya (finansial), atau sama.

c. Tapi jika harta qimi dirusak, maka harus diganti sesuai dengan keinginanya, walaupun tanpa izin dari pihak lain. Berbeda dengan harta qimi walaupun mungkin 
jenisnya sama, tapi nilainya bisa berbeda, dengan demikian pengambilan harus atas izin orangorang yang berserikat.

d. Harta mitsli rentan dengan riba fadl. Jika terjadi pertukara diantara harta mitsli, dan tidak terdaat persamaan dalam kualitas, kuantitas, dankadarnya, maka akan terjebak dalam riba fadl. Berbeda dengan harta qimiyang relatif resisten terhadap riba. Jika dipertukarkan dan terdapatperbedaan, maka tidak ada masalah. Diperbolehkan menjual satu domba dengan dua domba.

Ketiga, mal istihlak dan mal isti'mal. mal istihlak adalah harta yang dalam pemakainannya harus menghabiskannya atau dengan kata lain hanya bisa dipakai satu kali pemakaian. Harta yang seperti ini dibagi menjadi dua bagian yaitu: harta istihlak haqiqi dan istihlak huquqi. Mal istihlak haqiqi adalah harta yang sudah dimanfaatkan kegunaannya dan sudah jelas habis wujudnya. Dengan artian bahwa harta yang seperti ini dalam pemanfaatannya habis langsung dan tidak membekas. Sedangkan istihlak huquqi adalah harta yang habis ketika digunakan tetapi wujud dari barang itu masih atau dengan kata lain hanya berpindah kepemilikan. Sedangkan harta isti'mal yaitu harta yang dapat dipakai berulang kali atau dengan kata lain dapat digunakan berulang-ulang dan tidak akan habis wujud dan hak kepemilkikannya. Barang yang seperti ini seperti buku, sepatu, celana, dan sejenisnya.

Keempat, mal manqul dan mal ghaiu manqul. Mal manqul yaitu harta yang dapat dipindahkan baik itu zat wujud dari satu tempat ke tempat yang lain. Harta dengan kriteria ini mempunyai sebuah keunggulan dalam bidang dapat dipindah-pindakan dari satu tempat ketempat yang lain. Sedangkan mal ghair manqul(tidak bergerak) ialah harta yang tidak dapat dipindah-pindah dari satu tempat ke tempat yang lain, dan mempunya sifat tetap dan tidak bergerak.

Kelima, mal 'ain dan mal dayn. Mal 'ain yaitu harta yang berbentuk benda, seperti rumah, pakaian, dan lainnya. Harta yang seperti ini terbagi dalam dua jenis, yaitu:

a. Harta 'ain dzati qimah yaitu benda yang memiliki bentuk yang dipandang sebagai harta karena memiliki nilai.

b. Harta 'ain ghair dzati qimah yaitu benda yang tidak dapat dipandang sebagai harta karena tidak memilki nilai, misalnya sebiji beras. 
Adapun mal dayn adalah harta yang berada dalam tanggung jawab seseorang atau harta yang dihutang orang lain. Sehingga harta tersebut beralih tanggung jawab kepada orang lain atau pihak penghutang.

Keenam, mal al-'Ain dan mal al-Naf'i. Mal al- 'ain ialah benda yang memiliki nilai dan berwujud. Hal yang ini mempunyai pengertian bahwa benda yang mempunyai nilai dan benda itu juga mempunyai wujud maka hal itu bisa disebut dengan harta. Sedangkan mal al-Naf'i adalah harta yang berangsur-angsur tumbuh menurut perkembangan masa, oleh karena itu mal al-naf' $i$ tidak berwujud dan tidak disimpan.

Ketujuh, mal qabil li al-Qismah dan mal ghair qabil li al-Qismah. Mal qabil li al-Qismah adalah harta yang dapat dibagi. Harta yang tidak menimbulkan kerugian atau kerusakan pada harta apabila harta itu dibagi. Misalnya beras dan tepung. Sedangkan mal ghair qabil li al-Qismah) ialah harta yang tidak dapat dibagi dan akan menimbulkan kerusakan dan kerugian apabila harta itu dibagi-bagi. Misalnya meja, gelas, pensil, dan sejenisnya.

Kedelapan, mal ashal dan mal tsamarah (harta pokok dan harta buah). Harta pokok adalah harta yang mungkin darinya terjadi harta yang lain (harta modal). Misalnya bulu domba dihasilkan dari domba, maka domba asal bulu itu disebut harta modal. Sedangkan bulu domba itu disebut sebagai harta hasil (buah). Harta modalnya disebut harta pokok dan hasilnya disebut sebagai tsamarah.

Kesembilan, mal khas dan mal 'am. Mal khas yaitu harta pribadi, yang mana dalam pemilikannya tidak bersekutu dengan orang lain dan yang boleh mengambil kemanfaatannya hanya orang yang punya saja. Sedangkan $\mathrm{mal}$ ' $\mathrm{am}$ adalah harta milik umum (bersama) yaitu harta yang boleh diambil manfaat oleh umum atau bersama-sama. Dalam harta yang seperti ini bukan dalam maksud harta yang dimiliki oleh khalayak umum pada umumnya atau benda yang belum ada yang punya.

\section{Sebab-sebab Kepemilikan Harta}

Adapun sebab-sebab kepemilikan harta yaitu ${ }^{15}$ :

a. Ihraz al-mubahat, yaitu cara kepemilikan melalui penguasaan harta yang belum dimiliki seseorang, bandan hukum, yang dalam Islam disebut sebagai mubahat. Seperti, mengambil kayu

\footnotetext{
${ }^{15}$ Lukman Hakim, Prinsip-prinsip Ekonomi Islam,(Jakarta: Erlangga, 2012), hlm. 13
} 
di hutan belantara yang belum menjadi milik seseorang.

b. Melalui transaksi (akad), seperti transaksi jual beli.

c. Warisan,yaitu harta yang diperoleh seseorang dari peninggalan ahli warisnya.

d. Tawallud min mamluk, yaitu harta yang berasal dari suatu harta yang telah dimiliki. Seperti anak kambing yang lahir dari seekor kambing yang telah dimiliki, buah dari kebun yang dimiliki, tabungan dari investasi, dan hasil dari saham di perusahaan.

e. Harta pemberian negara yang diberikan kepada rakyat.

f. Harta yang diperoleh seseorang dengan tanpa mengeluarkan harta atau tenaga apa pun.

\section{Kedudukan Harta Dalam Al-}

\section{Qur'an dan Hadis}

Kata mal dalam Al-Qur'an, disebut sebanyak 86 kali pada 76 ayat dalam 38 surat, suatu jumlah yang cukup banyak menghiasi sepertiga surah-surah Al-Qur'an. Dari 86 kata mal berbentuk mufrad dengan berbagai lafal, selanjutnya 61 kali dalam bentuk isim jama' (amwal) dan jumlah ini belum termasuk kata-kata yang semakna dengan mal, seperti rizq, qintar, mata', dan kanz. ${ }^{16}$

Ada banyak ungkapan yang disebutkan oleh Alquran dalam memaknai harta dan mendudukkan pada posisi yang sebenarnya, hanya saja karena ayat-ayat tentang harta sangat banyak penulis tidak akan menguraikan seluruh ayat-ayat terkait harta, penulis hanya akan menguraikan sebagian yang bisa menjelaskan tentang kedudukan harta. Untuk menyempurnakan pembahasan tentang harta penulis juga menguraikan hadishadis yang menyinggung masalah harta. Sebagaimana disinggung di atas bahwa dalam Islam pemilik harta secara mutlak adalah Allah SWT. Harta diberikan kepada hamba-Nya sebagai amanah yang harus dipegang dengan baik, sebagai perhiasan yang menambah kebahagiaan dalam hidup, sebagai ujian keimanan, dan sebagai bekal ibadah. Dalam Alquran dan hadis, kedudukan dan implikasi harta digambarkan sebagai berikut:

a. Pemilik mutlak harta adalah Allah SWT

Pemilik mutlak harta adalah Allah SWT, sedangkan kepemilikan manusia terhadap harta hanya

${ }^{16}$ Tarigan, Azhari Akmal, Tafsir Ayat-ayat Ekonomi Sebuah Eksplorasi Melalui Kata-kata Kunci dalam al-Qur'an, (Bandung: Cita Pustaka Media Perintis, 2012), hlm. 90 
bersifat relatif. Ayat Alquran yang berbicara tentang kepemilikian mutlak adalah Allah dalam Alquran sungguh banyak, antara lain, dalam surah Thaha/ 20:6, Allah berfirman:

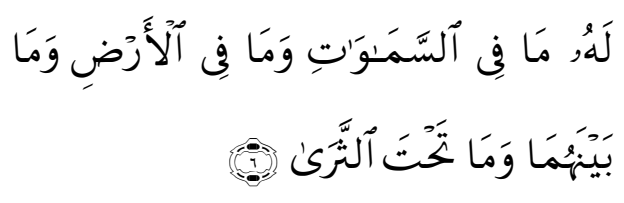

Artinya: "Kepunyaan-Nya-lah seтиa yang ada di langit, semua yang di bumi, semua yang di antara keduanya dan semua yang di bawah tanah."

Berdasarkan ayat ini semua yang ada di langit dan di bumi adalah milik Allah, berada dalam genggaman kekuasaan-Nya, dan berada dalam pengaturan-Nya, kehendak dan keinginan serta hukum-Nya. Dialah Yang Menciptakan semuanya, Yang Memilikinya, dan yang menjadi Tuhannya. Seluruh makhluk yang ada di bumi dan langit, termasuk manusia, hewan, harta dan semuanya adalah milik Allah, manusia hanya bisa memanfaatkannya, namun bukan pemilik sebenarnya, manusia hanya diberi ilmu pengetahuan agar bisa memanfaatkan semua yang ada di bumi-Nya, itupun masih banyak harta yang belum bisa dimanfaatkan karena keterbatasan kemampuan manusia. ${ }^{17}$ Implikasi dari kedudukan ini adalah bahwa manusia tidak boleh sombang, angkuh, dan kikir terhadap harta, karena pada akhirnya akan kembali pada-Nya. Manusia wajib mengeluarkan sebagian hartanya sebagai wujud kesyukurannya, karena dia telah dipercayai oleh Allah swt untuk mengelola harta tersebut.

Dalam hadis nabi saw: "Dari Zubair bin Awam ia berkata, Rasulullah SAW bersabda: "Negara adalah milik Allah, hamba (semua manusia) juga milik Allah di mana saja engkau mendapatkan kebaikan maka tegakanlah (bermukimlah)"

Hadis ini memberikan pengertian bahwa negara di mana pun adalah milik Allah, oleh karena itu manusia bisa tinggal di manapun yang ia suka, tentu saja dengan aturan-aturan yang berlaku, orang seharusnya boleh memilih kewarganegaraan, bekerja ke luar negeri untuk mencari penghasilan dan lain sebagainya, begitu pula hamba atau manusia milik Allah, tidak ada perbedaan derajat di antara mereka kecuali taqwa. Implikasinya, bahwa setiap manusia bisa saling mengenal,

\footnotetext{
${ }^{17}$ Tarigan, Azhari Akmal, Tafsir Ayatayat.., hlm. 96
} 
menjalin kerjasama dalam segala hal maupun mendapatkan pasangan hidup dengan manusia di mana pun berada. Inilah ajaran Islam semua manusia setara karena manusia seluruhnya adalah hamba Allah yang mempunyai kewajiban sebagai hamba untuk beribadah hanya menyembah kepada-Nya. Kemutlakan harta pada tangan Allah member pelajaran kepada manusia, bahwa manusia itu tidak memiliki apa pun tanpa kasih saying dan bantuan dari Allah swt.

b. Harta sebagai amanah/titipan Allah SWT berfirman dalam Surat al-Hadid/ 57: 7 sebagai berikut:

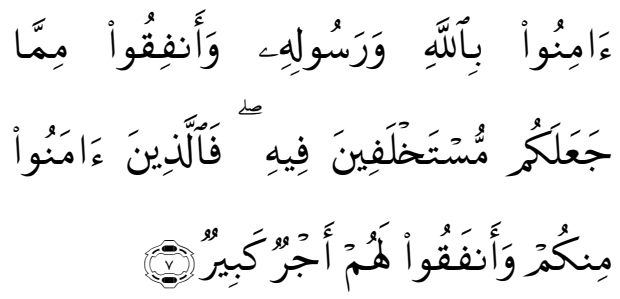

Artinya : "Berimanlah kepada Allah dan Rasul-Nya dan infakkanlah (di jalan Allah) sebagian harta yang telah Dia menjadikan kamu sebagai penguasanya (amanah). Maka orangorang yang beriman di antara kamu dan menginfakkan

(hartanya di jalan Allah) memperoleh pahala yang besar".

Dalam ayat di atas menjelaskan pada hakikatnya harta hanya titipan dari Allah, manusia hanya dititipi, ia tidak akan memilikinya terusmenerus, suatu saat Allah akan mengambilnya juga, baik melalui kematian, musibah, sakit dan lain sebagainya. Implikasi dari harta adalah titipan, bahwa supaya harta dapat kekal dimiliki selamanya dan bisa dibawa sampai ke akhirat, harta tersebut harus dikembalikan kepada Allah swt dengan cara disalurkan melalui zakat, infak dan sedekah atau wakaf. Atau bisa juga dengan cara distribusi lain seperti hibah atau hadiah.

Hal ini sangat penting dilakukan oleh manusia, karena bagi siapa saja yang diberi amanah harta di dunia, maka di akhirat akan dimintai pertanggungjawaban, sebagaimana Rasulullah bersabda:

Dari Abu Barzah Al-Aslami berkata: Rasulullah SAW bersabda:"Pada hari kiamat kelak seorang hamba tidak akan melangkahkan kakinya kecuali akan ditanya tentang empat perkara; tentang umurnya untuk apa ia habiskan, tentang ilmunya sejauh mana ia mengamālkannya, tentang hartanya darimana ia mendapatkannya dan untuk apa ia pergunakan, serta tentang sетиа anggota tubuhnya apa yang ia perbuat dengannya." (HR. Tirmidzi).

Hadis di atas mengingatkan manusia, bahwa harta merupakan 
amanah yang harus dikelola dengan hati-hati, dalam mencari dan menggunakannya harus benar, karena di hari kiamat akan diminta pertanggung jawabannya. Jika salah dalam cara memperolehnya dan tidak benar dalam menggunakannya, maka harta akan membuat manusia celaka di akhiratnya. ${ }^{18}$ Harta yang awalnya bertujuan membantu dan mempermudah manusia dalam menjalani hidup di dunia, akan berakhir petaka jika salah dalam pengelolaannya.

Lebih lanjut Tarigan, membagi empat kelompok manusia dalam mengelola hartanya, kelompok pertama yaitu mereka yang mendapatkan harta dengan cara yang halal dan menggunakannya dengan cara yang halal; kelompok kedua yaitu, mereka mengumpulkan harta dengan cara yang halal namun digunakan untuk sesuatu yang haram; kelompok ketiga, adalah mereka yang mengumpulkan harta dari jalan haram dan menggunakannya untuk sesuatu yang haram; dan kelompok keempat adalah mereka yang mengumpulkan harta dengan cara yang haram kemudian menggunakannya untuk yang halal, demikian pula harta digunakan untuk sesuatu yang halal namun disertai riya'. Menurut penulis, manusia dapat mendeteksi sejak dini, termasuk dalam kelompok manakah dirinya, dan bisa memilih mau masuk ke dalam kelompok mana. Supaya dapat selamat di dunia dan akhirat harusnya masuk dalam kelompok pertama.

c. Harta sebagai bekal ibadah

Allah berfirman dalam surah atTaubah/ $9: 41$

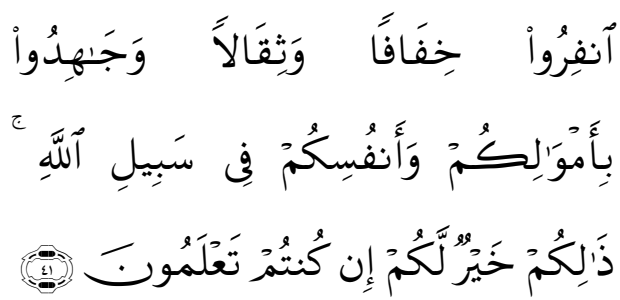

Artinya: "Berangkatlah kamu baik dalam Keadaan merasa ringan maupun berat, dan berjihadlah kamu dengan harta dan dirimu di jalan Allah. yang demikian itu adalah lebih baik bagimu, jika kamu mengetahui."

Ayat 41 surat at-Taubah ini menegaskan bahwa kedudukan harta dalam Islam sangat penting, yaitu sebagai sarana beribadah. Baik ibadah vertical maupun horizontal. Seperti Shalat, zakat, haji, sedekah, dan jihad di jalan Allah. Semua aktivitas manusia membutuhkan harta. Implikasi dari 
ini adalah bahwa seorang Muslim seharusnya memiliki harta, agar dapat melaksakan ibadah secara sempurna. Dan hai ini dapat dilaksanakan jika manusia memiliki pribadi yang baik. Jika harta itu bisa memilih, maka pastilah ia akan memilih diberikan pada orang yang baik. Dalam sebuah hadis Rasul SAW bersabda:

"Sebaik-baik harta yang baik adalah harta yang dimiliki oleh hamba yang baik." (HR. Ahmad).

Dalam hadis ini Rasul SAW menjelaskan bahwa harta tidak langsung mempunyai manfaat dan mudharat, harta ibarat sebilah pisau, ia akan bermanfaat jika yang memegangnya adalah koki untuk memasak masakan. Akan tetapi jika pisau dipegang oleh orang jahat, pisau akan menjadi alat untuk menakut-nakuti, melukai, bahkan membunuh manusia. Artinya jika harta dimiliki oleh orang baik, harta akan sangat bermanfaat sebagai sarana menunaikan ibadah dan kemaslahatan umum. Namun bila harta dimiliki oleh orang jahat harta akan sangat berbahaya, karena bisa merusak sendi-sendi perekonomian dan kemaslahatan masyarakat.

d. Harta sebagai perhiasan
Harta itu diciptakan oleh Allah untuk membantu manusia dalam menghadapi hidupnya. Menambah keindahan dunia dan menjadi fitrah manusia bahwa ia akan selalu mencintai harta sampai ajal tiba. Allah SWT menetapkan demikian sebagaimana firman-Nya dalam surah Ali Imran/ 3: 14:
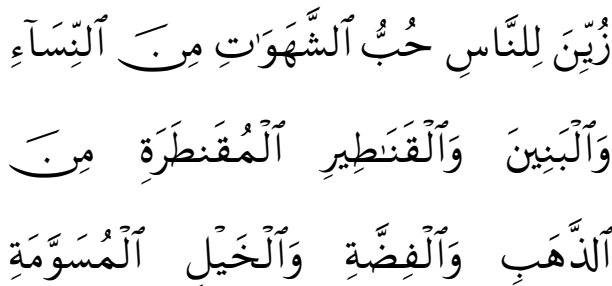

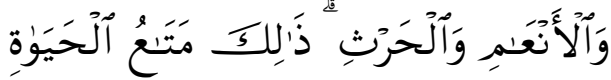

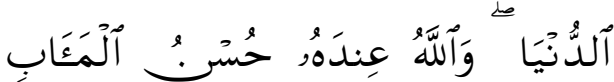

Artinya : "Dijadikan indah pada (pandangan) manusia kecintaan kepada apaapa yang diingini, Yaitu: wanita-wanita, anakanak, harta yang banyak dari jenis emas, perak, kuda pilihan, binatangbinatang ternak dan sawah ladang. Itulah kesenangan hidup di dunia, dan di sisi Allahlah tempat kembali yang baik (surga).

Dalam ayat yang lain Allah berfirman dalam surah al-Kahf/ $18: 46$ 
Le

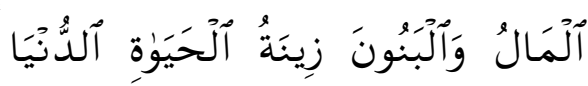

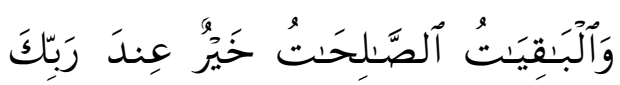

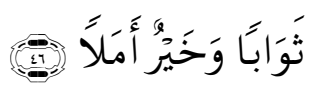

Artinya : "Harta dan anak-anak adalah perhiasan kehidupan dunia tetapi amalan-amalan yang kekal lagi saleh adalah lebih baik pahalanya di sisi Tuhanmu serta lebih baik untuk menjadi harapan."

Dalam ayat di atas dijelaskan bahwa harta adalah salah satu perhiasan hidup. Disebutkan kekayaan dan anak-anak adalah perhiasan kehidupan dunia. Ibarat sebuah perhiasan, jika digunakan pada waktu dan tempat yang tidak sepatutnya, maka pasti terlihat jelek. Demikian pula dengan harta ini. Karena itu Allah menegaskan bahwa hanya sesuatu yang lebih bermanfaat dan membahagiakannya adalah amalan-amalan yang kekal lagi baik.

Implikasi dari kedudukan harta sebagai perhiasan adalah bahwa manusia tidak boleh terlena dengan hartanya. Seharusnya harta tersebut tidak melalaikannya dalam melakukan amalan-amalan yang baik dan bermanfaat. Manusia harus memenuhi hak-hak Allah dan hak-hak sesama manusia berupa shalat, zakat, sedekah, haji, umrah, bertasbih (mengucapkan) tahmid, tahlil dan takbir, membaca (Alquran), mencari ilmu yang bermanfaat, melakukan amar ma'ruf nahi munkar, menjalin tali silaturahmi, berbakti kepada kedua orang tua, melaksanakan hak-hak istri, budak-budak dan hewanhewan serta seluruh jenis perbuatan baik yang ditujukan kepada sesama manusia.

Itulah termasuk baqiyyatu assalihat (amalan-amalan yang kekal lagi baik). Amal perbuatan ini lebih baik pahalanya di sisi Allah dan lebih baik untuk menjadi harapan. Pahalanya lestari dan berlipat ganda selama-lamanya. Pahala, kebaikan, dan kegunaan amalan itu senantiasa diharap-harap di waktu yang diperlukan. Inilah yang sepatutnya menjadi perlombaan bagi manusia untuk meraihnya. Bukan berlombalomba dalam mengumpulkan dan menumpukkan harta.

\section{Penutup}

Kedudukan harta dalam Alquran dan hadis sangat jelas. Yaitu milik Allah SWT yang diamanahkan kepada manusia, titipan, alat, dan perhiasan, serta ujian bagi manusia. Implikasinya adalah bahwa manusia dituntut untuk selalu mempergunakan harta itu sesuai dengan 
tuntunan dan petunjuk pemiliknya yaitu Allah SWT. Dalam kehidupan manusia, harta dapat berfungsi untuk memenuhi kebutuhan pribadi pemilik harta dan juga berfungsi memenuhi kebutuhan sosial.

Alquran dan hadis juga memberikan tuntunan tentang cara-cara memperoleh harta dan mengelola serta membelanjakannya. Memperoleh harta dapat dilakukan dengan cara seperti menguasai benda-benda mubah yang belum dikuasai manusia, perjanjian/ transaksi perpindahan hak milik, melalui warisan, hak syuf'ah, hak-hak seseorang yang diatur oleh agama. Adapun cara mengelola dan membelanjakannya adalah menentukan prioritas kebutuhan, berdasarkan prinsip halalan tayyiban, menghindari boros dan tabzir, memperhatikan prinsip kesederhanaan, ada alokasi sosial, dan untuk alokasi masa depan.

\section{DAFTAR PUSTAKA}

Hakim, Lukman. Prinsip-prinsip Ekonomi Islam. Jakarta: Erlangga. 2012.

Hasan, M. Ali. Berbagai Macam Transaksi dalam Islam. Jakarta: PT Raja Grafindo Persada. 2003.

Muhammad Daud Ali, Sistem Ekonomi Islam Zakat dan Wakaf Cet.1, Jakarta: Penerbit Universitas Indonesia (UI-Press), 1988.

Muhammad Hasbi Ash Shiddieqy, Teungku. Pengantar Fiqh Muamalah. Semarang: PT. Pustaka Rizki Putra. 2001.
Muhammad Hasbi Ash Shiddieqy, Teungku. Pengantar Hukum Islam. Semarang: PT. Pustaka Rizki Putra. 2001.

Suhendi, Hendi. Fiqh Muamalah. Jakarta: PT Raja Grafindo Persada. 2002.

Tarigan, Azhari Akmal. Tafsir Ayat-ayat Ekonomi Sebuah Eksplorasi Melalui Kata-kata Kunci dalam alQur'an. Bandung: Cita Pustaka Media Perintis. 2012. 